\title{
PRODUCTS OF COMBUSTION OF THE METAL POWDERS
}

\author{
T. P. Sharma \\ Fire Research Laboratory, \\ Central Building Research Instt. \\ Roorkee 247667 (U.P.) India \\ B.S. Varshney \\ and \\ Surendra Kumar \\ Chemical Engineering Department, \\ University of Roorkee \\ Roorkee 247667 (U.P.) India \\ (Received, August 20, 1991, Accepted, March 15, 1992)
}

\begin{abstract}
Sophistication in the aviation and warfare technologies has significantly increased the use of metals such as aluminium, magnesium and their alloys for numerous applications. The resulting fires of such metals are probably one of the most dominating and devastating risks if the metals are in the form of fine particles. The work consists of determination of the constituents of the various combustion products after the burning of the magnesium, aluminium and aluminiummagnesium alloy powder heaps on the sand bed. The analysis of the ground products of burnt metal powders on the sand bed has been carried out by using X-ray diffractometer. It is found that oxides and nitrides were the predominant fractions of the combustion products of the metal powders. Interestingly, it is also found that the combustion products of the aluminium, and the aluminium-magnesium alloy powder heap on the sand bed contain free aluminium also.
\end{abstract}

\section{INTRODUCTION}

Various studies $[1,2]$ have been carried out dealing with the conditions under which fire hazards of metals may or may not take place. It has been found that besides the metals themselves, their shape and the size are important parameters in assessing their fire hazards. Heavier pieces of metals such as ingots, thick wall castings, and other pieces of thickness over $9 \mathrm{~mm}$ [3] are difficult to ignite because heat is conducted rapidly away from the place of initiation of ignition; hence they are safe and accordingly, stored in open sheds [3]. Sharma [4] has carried out extensive literature survey and found that thick pieces could also be ignited if they are continuously heated with the necessary amount of heat input. In contrast, if the metals are available in the form of ribbons, shavings or chips with feather like edges or grinding dusts, a spark or a tiny flame may be sufficient to set the material on fire. It is due to this reason that open flames, lights, smoking, electric or gas welding or cutting, which produce hot particles or spark, are prohibited in the section of the building where dust of these metals is processed or handled.

Magnesium, aluminium and their alloy powders are susceptible to fires and thereby lead to hazards. Severe fire hazards have also occurred when large quantities of these metals are exposed to intense heat if they are in the molten state. In fact, the reactivity of aluminium and magnesium metals is so high that they react with all the commonly available extinguishing agents such as water, carbon dioxide, foam, and dry chemical powders, and continue to burn even in the presence of nitrogen, chlorine and carbon forming 
their nitrides, chlorides and carbides respectively.

While controlled combustion of metals is virtually very important in aviation and warfare technologies, it is very difficult to determine or estimate the reaction rates and temperatures attained by them either by experimental or computational techniques. According to Markstein [5], the metals as well as their products during combustion are usually in the condensed state. That is the reason that they burn predominantly by heterogeneous reaction process. The mechanisms in most of the cases are generally unknown, therefore, neither their overall rates nor the rates of participating elementary reaction steps could be determined.

Yuasa and Takeno [6] explained in detail the process leading to development of their particles cloud flame. They described it essentially a nonsteady phenomenon in which the interaction among the ignited and non-ignited particles played a significant role. The process leading to development of 50-50 aluminium-magnesium alloy powder particles into their cloud flame is shown in Fig. 1 and 2. They explained that the state of particle cloud flame depended on the development of ignition kernel through collisions between ignited and non-ignited particles and the radiative heat transfer from the flamelet to the non-ignited

(2)

$$
\text { Mg vapour diffusion flame }
$$
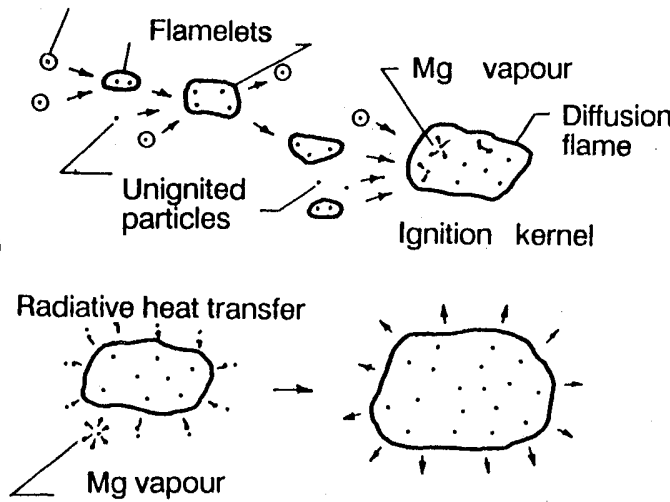

Flame propagation through partially premixed gas

Figure 1'. Schematic representation of ignition process leading to development of particle cloud flame. particles increased with the size of the flamelet resulting in a sort of explosion. Thus, all injected alloy particles were involved in this process resulting in a single continuous flame.

Since it is important to know the extent of combustion of the metal powder fires, it would be interesting to find out their products of combustion as a sequel to the combustion of metal. Markstein [7] carried out investigations on magnesium
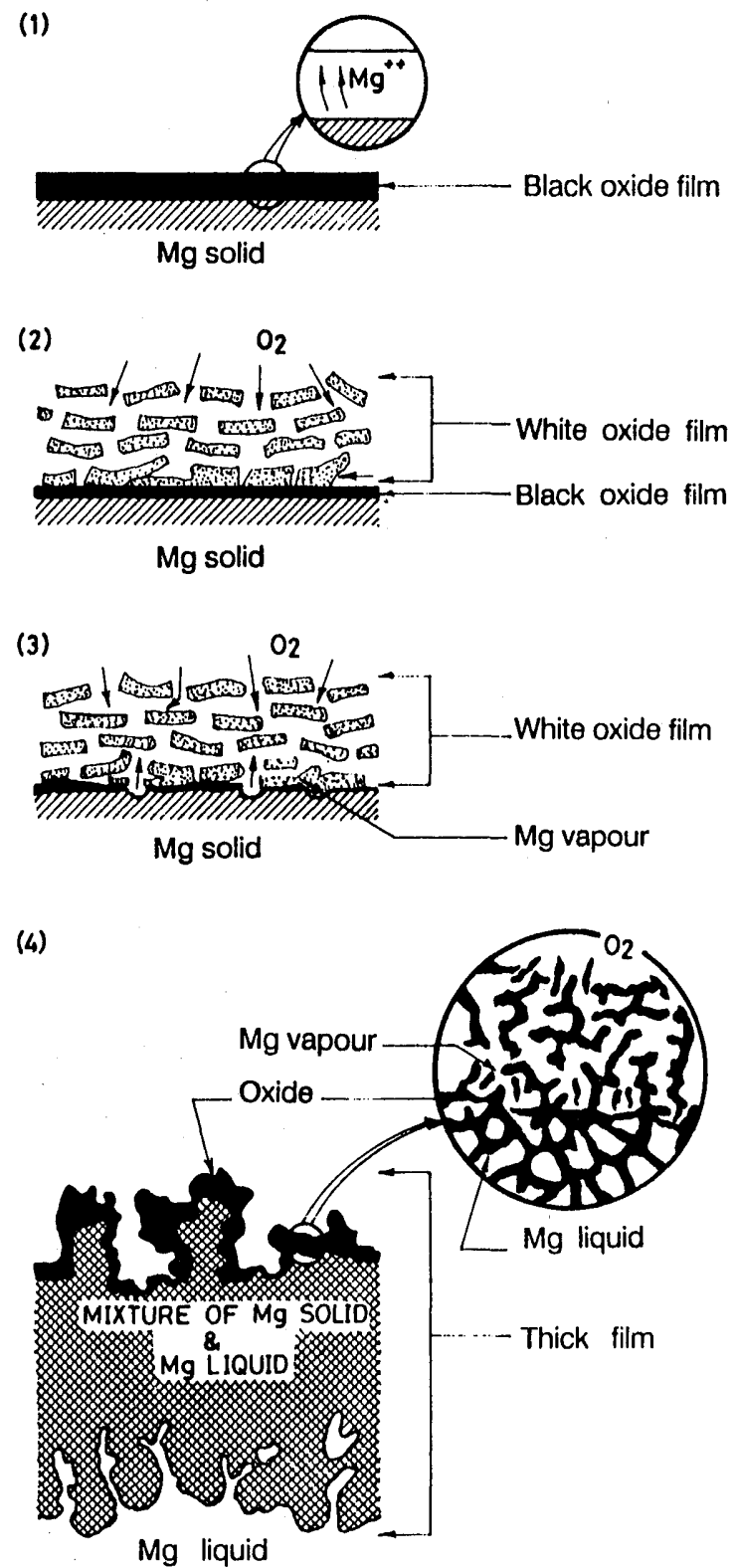

Figure 2. Schematic representation of four stages in surface oxidation. 
vapours in oxygen-argon atmosphere obtaining dilute diffusion flame. The magnesium oxide, formed in the diffusion flame, collected as a fluffy transluscent white layer on all surfaces within the combustion chamber. They found the emission of a continuous radiation, with a broad maxima at about $4500 \AA$ and narrowed maxima at about 3900 , 6000,6500 and $6900 \AA$. It was concluded that the spectra of the flame of a magnesium ribbon burning in air at atmospheric pressure, contained the $\mathrm{MgO}$ band at about $5000 \AA$. The bands at $3700 \AA$ and $3820 \AA$ were attributed partly to the magnesium hydroxide $\mathrm{Mg}(\mathrm{OH})_{2}$ and a number of magnesium lines.

Yuasa and Isoda [8] ignited magnesium metal in the stream of $\mathrm{CO}_{2}$ and found a black crust with white powder to cover the sample receptacle inside which no residue existed. The corresponding flame spectrum showed the atomic lines of magnesium and the bands of magnesium oxide.

Yuasa [9] carried out experiments to study emission spectra of magnesium flames with carbon dioxide for understanding combustion process of the metals in carbon dioxide atmosphere. He found that magnesium continued to burn with incandescent flames with a large amount of white smoke for a period of 30 to $40 \mathrm{~s}$ attaining temperatures in the range of 1273 to $1323^{\circ} \mathrm{K}$. He claimed that in the emission spectrum the atomic lines of magnesium, the bands of magnesium oxide vapours, and the continuous emission of condensed magnesium oxide were visible. The identified lines and bands were of: Magnesium singlets-285.21 nm, $457.11 \mathrm{~nm}$; Magnesium triplets-309.11, 309.3, 309.69nm (weak); and Magnesium oxide bands-500.73 nm (strong, broad heads), 372.14, 372.57, $373.18 \mathrm{~nm}$ (strong).

It is interesting to note that several other investigators such as Brzustowski and Glassman [10], Sullivan and Glassman [11], and Takeno and Yuasa [12] also observed similar results on the products of metal combustion.

\section{EXPERIMENTAL SET UP \& PROCEDURE}

The experimental setup, procedure and reasons for adopting the experimental procedure for burning magnesium, aluminium and aluminiummagnesium alloy powders in the form of heap on the sand bed under normal atmospheric conditions have been described in our paper [13] and has been illustrated in Fig. 3. All the three metal powders, used in these experiments, are placed on the sand bed. The height of all the individual heaps was kept $25 \mathrm{~mm}$ and diameter was varied depending on the bulk density of individual metal powder. All the metal powders were ignited individually by $2 \mathrm{~g}$ of magnesium powder placed in the mild steel spoon and was held in the flame of a liquified petroleum gas burner until the metal powder ignited. The burning powder was gently dropped into the cavity at the top of the individual powder heaps placed on the sand bed [13].

The experimental setup, which was used to identify the microcrystalline high temperature phases constituting the main bulk of combustion products of metal powders on sand beds, mainly consists of a Philips X-ray Diffractometer (Model PW 1730) coupled with automatic channel controller (Model PW 1773) for recording $\mathrm{mV}$ signals from the proportional detector (PW 1965/60). The $\mathrm{X}$-ray diffraction unit is fitted with a vertical goniometer assembly (PW1050/70) and X-ray tube with copper anode. The instrument was operated using nickel filter for obtaining monochromatic $\mathrm{X}$-ray beam ( $\mathrm{CuK} \alpha$-radiations).

Before analysing the combustion products [13] of a $100 \mathrm{~g}$ of the magnesium powder heap on the sand bed by the X-ray diffractometer, the products were first ground to a size of less than 45 micron so that sufficient grains of various constituents contribute to the diffraction of X-ray beam. Then the diffraction patterns for the powder samples were obtained using $\mathrm{CuK} \alpha$-radiations at $30 \mathrm{KV}$ and $20 \mathrm{~mA}$ of power setting with nickel filter. The X-ray diffractometer was operated at the scanning rate of $1^{\circ} / \mathrm{min}$ (rate of change of goniometer angle), chart speed of $0.5 \mathrm{~cm} / \mathrm{min}$, and recording range of 4000 counts per sec. with time 

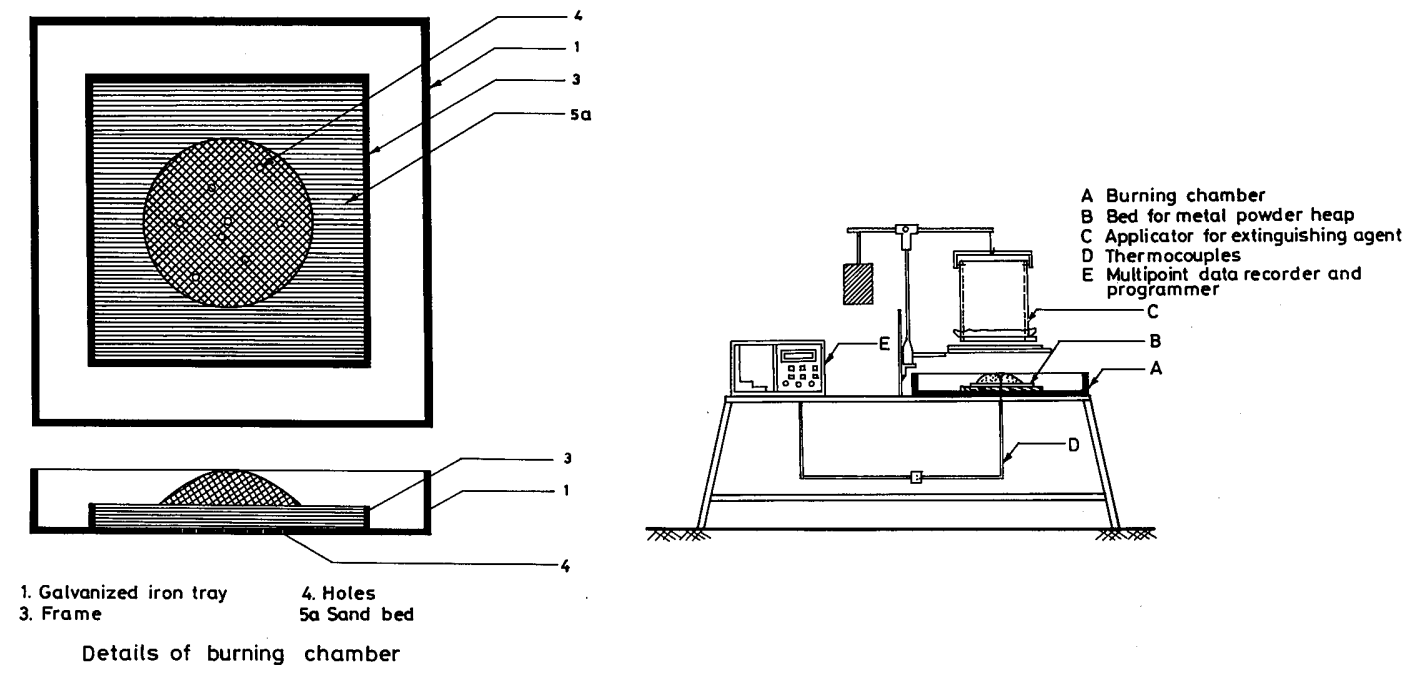

Figure 3. Schematic diagram of experimental setup.

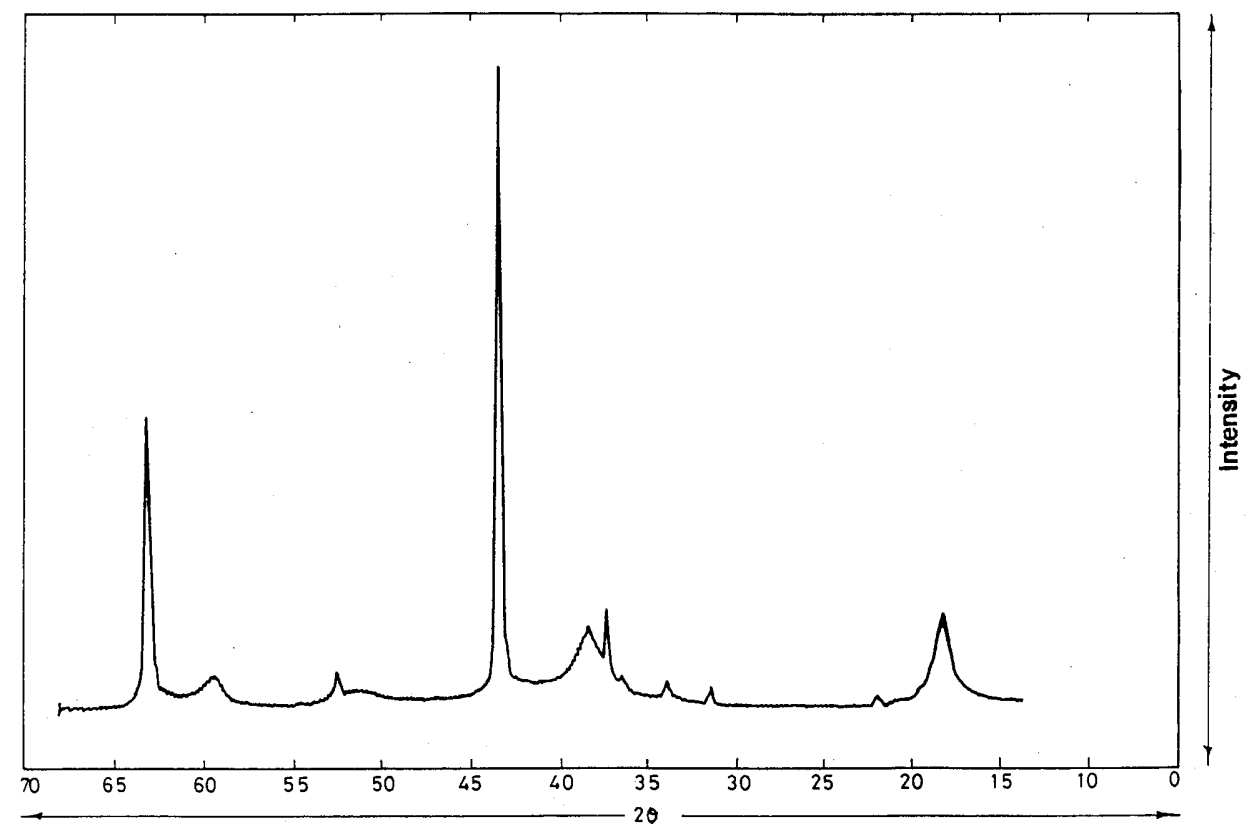

Figure 4. X-ray diffraction pattern of combustion products of the magnesium powder heap on the sand bed.

constant of unity.

Similarly, the samples of combustion products of a $100 \mathrm{~g}$ of each of aluminium, and aluminiummagnesium alloy powder heaps on the sand bed were also analysed.

\section{RESULTS AND DISCUSSION}

Identifications of high temperature microcrystalline phases formed during the burn- ing of $100 \mathrm{~g}$ of the individual metal powder heaps on the sand bed ( $25 \mathrm{~mm}$ thick) were carried out by $\mathrm{X}$-ray diffraction technique. The details of experimental set up and the procedure adopted have already been given in the earlier section. The combustion products of $100 \mathrm{~g}$ metal powder in form of the heap on the sand bed after its burning and then cooling to ambient temperature were first ground for the particle sizes less than 45 
micron. Then, X-ray diffraction patterns for the ground samples were obtained using Cuk $\alpha$-radiations.

The X-ray diffraction results for the combustion products of the magnesium, the aluminium and $61 \%$ aluminium-34\% magnesium alloy powders have been described in the following subsections.

\subsection{Combustion Products of the Magnesi- um Powder Heap}

The X-ray diffraction results for the combustion products, obtained as a result of the burning of the magnesium powder heap on the sand bed are shown in Fig. 4. and their analyses in Table 1. The lattice spacing, $d(\AA)$, for significant peaks appearing at different diffracted X-ray beam angle (2 values) in diffractograms were obtained using standard conversion tables [14]. These values of lattice spacings $d(\AA)$ for different products were compared with standard $d(\AA)$ values of oxide, nitride, hydroxide, free magnesium, silicon dioxide, etc., as reported in ASTM X-ray powder data file [14]. The inferences drawn on the basis of the Xray diffraction results, given in Tabel 1 , are:

The strong reflections corresponding to lattice spacings, $\mathrm{d}(\AA)$ of $1.48,2.11$ and 2.42 indicate the presence of magnesium oxide as a predominant constituent. In fact, these values correspond to strong intensities. It is also noted that the $d(\AA)$ values of $4.79,2.10$ and 2.35 confirm

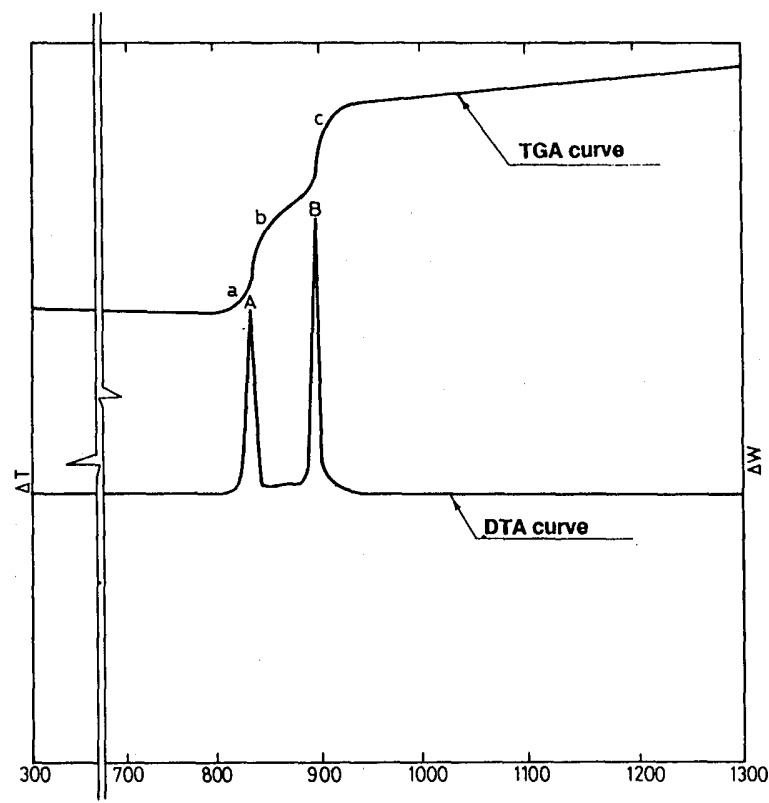

Figure 5. DTA and TGA of magnesium powder. (amount $10.00 \mathrm{mg}$, heating rate $10^{\circ} \mathrm{C} / \mathrm{min}$ )

the presence of $\mathrm{Mg}(\mathrm{OH})_{2}$. As a matter of fact, $\mathrm{Mg}(\mathrm{OH})_{2}$ is the product of hydration of $\mathrm{MgO}$, which is formed during burning of magnesium powder, in presence of atmospheric moisture. Hence, the presence of $\mathrm{Mg}(\mathrm{OH})_{2}$ indicates that burning of magnesium powder first leads to the formation of $\mathrm{MgO}$ as combustion product, which, further on hydration forms $\mathrm{Mg}(\mathrm{OH})_{2}$.

The weak and diffused bands/reflections corresponding to $d(\AA)$, lattice spacings of $2.86,2.65$, $2.49,2.10,1.75$ and 1.57 indicate the presence of

Table 1. The X-ray analysis of the combustion products of the magnesium powder heap on the sand bed.

\begin{tabular}{|c|c|c|c|c|c|c|c|}
\hline S.No. & $2 \theta$ & Intensity & $\mathrm{d}(\AA)$ & $\mathrm{Mg}_{3} \mathrm{~N}_{2}$ & $\mathrm{MgO}$ & $\mathrm{Mg}(\mathrm{OH})_{2}$ & Silicon dioxide \\
\hline 1 & 18.50 & S & 4.7918 & & & $4.77 / 90$ & \\
\hline 2 & 21.90 & VW & 4.0550 & & & & $4.04 / 100$ \\
\hline 3 & 31.20 & $\mathrm{~W}$ & 2.8642 & $2.87 / 20$ & & & $2.84 / 14$ \\
\hline 4 & 33.70 & W & 2.6572 & $2.66 / 27$ & & & \\
\hline 5 & 36.20 & W & 2.4793 & $2.49 / 20$ & & & $2.46 / 6$ \\
\hline 6 & 37.10 & $\mathrm{~S}$ & 2.4212 & & $2.431 / 100$ & & \\
\hline 7 & 38.10 & $\mathrm{~S}$ & 2.3599 & & & $2.37 / 100$ & $2.34 / 21$ \\
\hline 8 & 43.00 & VVS & 2.1016 & $2.12 / 42$ & $2.11 / 100$ & $2.11 / 100$ & $2.12 / 40$ \\
\hline 9 & 52.10 & $\mathrm{~W}$ & 1.7539 & $1.76 / 100$ & & $1.79 / 56$ & $1.75 / 1$ \\
\hline 10 & $\begin{array}{l}58.10 \\
59.00\end{array}$ & WD & $\begin{array}{l}1.5764 \\
1.5642\end{array}$ & $1.53-1.47$ & & $1.573-1.494$ & \\
\hline 11 & 62.40 & VS & 1.4869 & & $1.49 / 52$ & & \\
\hline
\end{tabular}




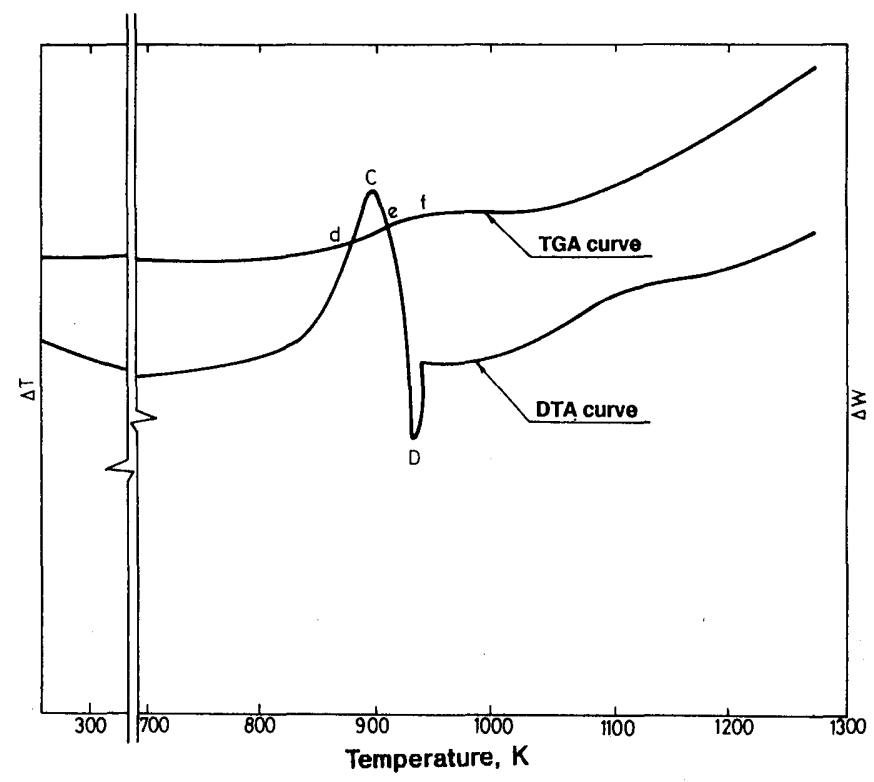

Figure 6 . DTA and TGA of aluminium powder. (amount $10.08 \mathrm{mg}$, heating rate $10^{\circ} \mathrm{C} / \mathrm{min}$ )

the magnesium nitride as a second predominant fraction in the combustion product.

The accessary reflections of weak and moderate intensities in the X-ray diffractometer pattern corresponding to lattice spacings, $\mathrm{d}(\AA)$ values of $4.05,2.86,2.47,2.34,2.12$ and 1.75 indicate the presence of silicon dioxide, a minor fraction in the combustion product, which could be attributed in the powder either as an impurity, or it may be due to the contamination of a very small quantity of sand at the interface between the magnesium powder heap and the sand bed.

It would be important to mention that Markstein [5] has reported the formation of $\mathrm{MgO}$ and $\mathrm{Mg}(\mathrm{OH})_{2}$ as combustion products of magnesium. However, he did not report the presence of $\mathrm{Mg}_{3}$ $\mathrm{N}_{2}$. An analysis of his experimental work reveals that he used oxygen-argon atmosphere for the burning of the magnesium vapours.

Therefore, the question of formation of $\mathrm{Mg}_{3}$ $\mathrm{N}_{2}$ did not arise in this case. Whereas in the present investigation, the burning behaviour of the metal powder has been studied under normal atmospheric conditions in presence of normal atmospheric air. Therefore, the formation of $\mathrm{Mg}_{3}$ $\mathrm{N}_{2}$, in addition to $\mathrm{MgO}$ and $\mathrm{Mg}(\mathrm{OH})_{2}$ is quite ob- vious. Further, investigations by Yuasa and Isoda [8], Yuasa [9], Brzustowski and Glassman[10], Sullivan and Glassman [11], and Takeno and Yuasa [12] support the findings of the present investigation.

In fact, the X-ray diffractometer analysis does not indicate the presence of unburnt free magnesium powder implying that all of a $100 \mathrm{~g}$ of the magnesium powder participated in the burning.

It is important to mention here that the DTA curve of the magnesium powder [13] in Fig.5 shows only two exothermic peaks ' $\mathrm{A}$ ' at $816 \mathrm{~K}$ and ' $\mathrm{B}$ ' at $871 \mathrm{~K}$ and no endothermic peak. Had there been some unburnt magnesium, it would have been represented in DTA cruve of magnesium powder as in the case of DTA curve of the aluminium powder. It is to be recalled that in the case of thermogram of aluminium powder [13] Fig. 6, an endothermic peak ' $\mathrm{D}$ ' at $933 \mathrm{~K}$ was obtained immediately after an exothermic peak ' $\mathrm{C}$ ', signifying melting of the aluminium. The absence of an endothermic peak in the DTA curve of the magnesium evidences clearly that there was no melting of magnesium and hence no free magnesium was present in the burnt powder. 
3.2 Combustion Products of the Aluminium Powder Heap

X-ray diffractometer was employed for identifying combustion products of aluminium powder similar to that used for the magnesium powder. Fig. 7 shows the results obtained from the diffractometer and the related analysis of Fig. 7, with the help of ASTM X-ray powder data file [14], is given in Table 2. The inferences drawn on the basis of $\mathrm{X}$-ray diffraction results, compiled in Table 2, are:

Strong reflections corresponding to lattice spacings, $\mathrm{d}(\AA)$ of $2.41,2.40,2.73,2.12,2.57$ and 2.59 indicate the presence of aluminium oxide. As a matter of fact, oxides of aluminium are present in different forms.

The strong reflections representing lattice spacings, $d(\AA)$ of $2.69,2.53,2.37,1.85,1.54$ and 1.32 indicate the presence of aluminium nitride as predominant fraction of the combustion products of aluminium powder. The behaviour is similar to that obtained in case of magnesium powder as burning behaviour experiments were carried out under ambient conditions.

The values of $d(\AA)$ spacings of $3.55,2.11 .1 .75$ and 1.58 suggest the presence of aluminium fluorosilicate (in traces) in combustion products.

Table 2. The X-ray analysis of the combustion products of the aluminium powder heap on the sand bed.

\begin{tabular}{|c|c|c|c|c|c|c|c|c|c|c|c|c|c|}
\hline 2 & Intensity & $\mathrm{d}(\AA)$ & $\begin{array}{c}\text { Aluminium } \\
\text { Nitride } \\
\text { AIN }\end{array}$ & $\begin{array}{l}\alpha- \\
\text { alumina }\end{array}$ & 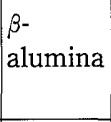 & $\begin{array}{l}\tau- \\
\text { alumina }\end{array}$ & $\begin{array}{l}\theta- \\
\text { alumina }\end{array}$ & $\begin{array}{l}\zeta- \\
\text { alumina }\end{array}$ & $\begin{array}{l}\varepsilon- \\
\text { alumina }\end{array}$ & $\begin{array}{l}\delta- \\
\text { alumina }\end{array}$ & $\mid \begin{array}{l}\phi- \\
\text { alumina }\end{array}$ & Aluminium & $\begin{array}{c}\text { Aluminium } \\
\text { Fluoro } \\
\text { Silicate }\end{array}$ \\
\hline 18.5 & VWD & 4.7918 & & & & & & & & & & & \\
\hline 18.8 & & 4.7160 & & & & & & & & & & & \\
\hline 25.0 & MS & 3.5587 & & & & & & & & & & & $3.52 / 100$ \\
\hline 31.2 & W & 2.8642 & & $2.82 / 80$ & & $2.87 / 80$ & & & & & $2.87 / 40$ & & \\
\hline 32.7 & WS & 2.7362 & & & & $2.74 / 80$ & & & & & $2.73 / 80$ & & \\
\hline 33.2 & & 2.6971 & $2.70 / 100$ & $2.69 / 100$ & & & & & & & & & \\
\hline 33.4 & & 2.6882 & & & & & & & & & & & \\
\hline 34.6 & S & 2.5902 & & & $2.57 / 100$ & & & & $2.59 / 80$ & & $2.58 / 30$ & & \\
\hline 35.4 & VVS & 2.5334 & $2.49 / 60$ & & & & & & & & $2.43 / 60$ & & \\
\hline 37.0 & W & 2.4275 & & & & & $2.43 / 60$ & & & & & & \\
\hline 37.2 & VVS & 2.4149 & & & & & & $2.40 / 60$ & $2.41 / 30$ & & & & \\
\hline 37.9 & MS & 2.3719 & $2.37 / 70$ & & & & & & & $2.40 / 50$ & & 2.338100 & \\
\hline 42.3 & $\mathrm{~W}$ & 2.1348 & & & & & & & & $2.13 / 20$ & $2.13 / 80$ & & \\
\hline 42.7 & $\mathrm{~S}$ & 2.1157 & & & $2.12 / 90$ & & & & & $2.11 / 30$ & & & $2.11 / 10$ \\
\hline 44.1 & $\mathrm{~S}$ & 2.0517 & . & & & & & & & & & $2.024 / 47$ & \\
\hline 45.0 & W & 2.0128 & & & & & $2.00 / 100$ & $1.99 / 80$ & & $2.024 / 47$ & $2.01 / 80$ & & \\
\hline 49.2 & VS & 1.8503 & $1.829 / 20$ & & & & & & & & & & $1.76 / 13$ \\
\hline 52.0 & W & 1.7571 & & & & & & & & & & & \\
\hline 56.9 & $\mathrm{~S}$ & 1.6968 & & & & & & & & & & & $1.58 / 10$ \\
\hline 58.7 & VS & 1.5715 & & & & & & & & & $1.54 / 40$ & & \\
\hline 60.0 & W & 1.5405 & $1.557 / 30$ & & & & & & & $1.53 / 10$ & & & \\
\hline 60.7 & VW & 1.5244 & & & & & & & & & $1.49 / 40$ & & \\
\hline 61.6 & & & & & & & & & & & $1.45 / 30$ & & \\
\hline 61.9 & WD & 1.5021 & & & & & & & & & & $1.431 / 22$ & \\
\hline 64.6 & W & 1.4415 & & & & & & & & & & & \\
\hline 65.4 & VS & 1.4257 & & & & & & & & & & & \\
\hline 65.9 & $\mathrm{~W}$ & 1.4161 & $1.414 / 20$ & & & $1.40 / 100$ & $1.40 / 100$ & $1.40 / 100$ & $1.40 / 100$ & & $1.40 / 100$ & & $1.40 / 100$ \\
\hline 67.6 & W & 1.3846 & & $1.39 / 100$ & $1.38 / 100 \mathrm{~B}$ & & & & & & & . & \\
\hline 69.1 & W & 1.3587 & $1.348 / 6$ & & & & & & & & & & $1.39 / 100$ \\
\hline 70.9 & MS & 1.3280 & $1.32 / 18$ & & & & & & & & & & \\
\hline 72.0 & $\mathrm{~S}$ & 1.3104 & $1.301 / 8$ & & & & & & & & & & \\
\hline
\end{tabular}




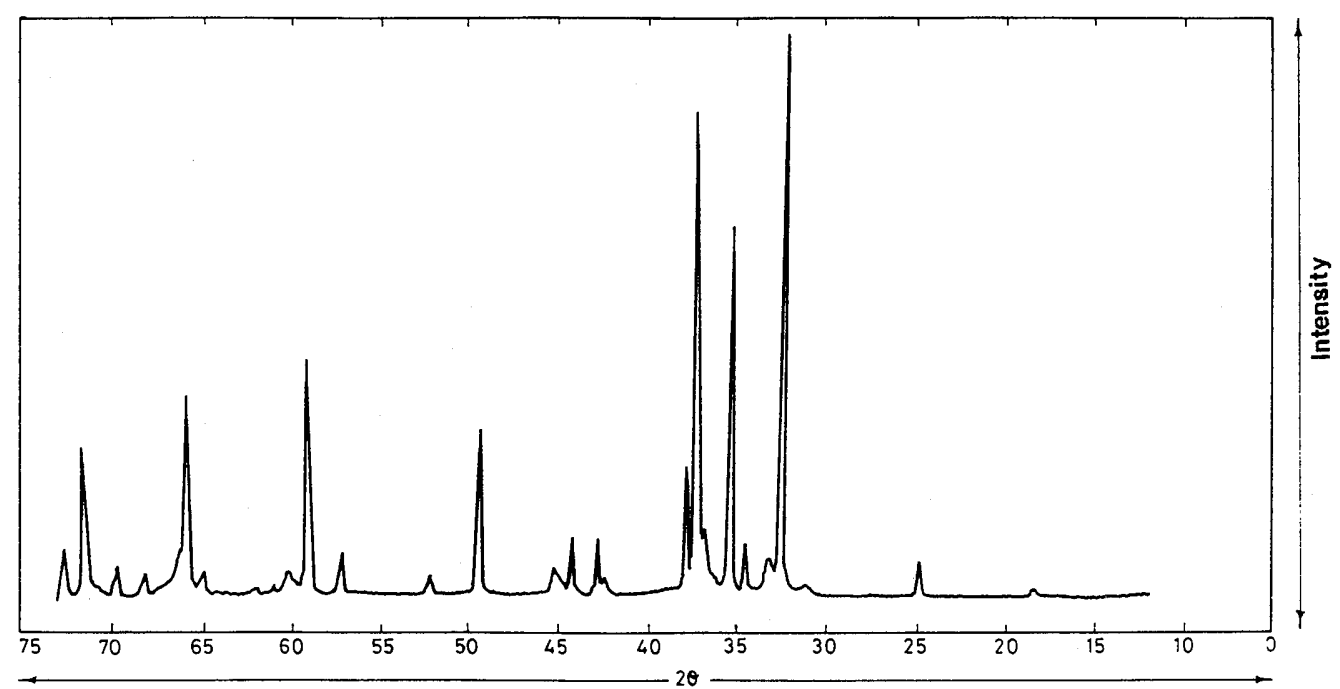

Figure 7. X-ray diffraction pattern of combustion products of the aluminium powder heap on the sand bed.

As regards the presence of unburnt free aluminium powder, it is also found in traces, as the corresponding $\mathrm{d}(\AA)$ values are $2.37,2.01$ and 1.42 . This is unlike the case of combustion products of magnesium powder where unburnt free magnesium was not found.

It is interesting to note that the presence of aluminium, as one of the combustion products, supports the proposition of Varshney et al [13] in which, based on DTA studies of the aluminium powder, the possibility of unburnt aluminium has been pointed out.

\subsection{Combustion Products of the Aluminium-Magnesium Alloy Powder Heap}

Like combustion products of the magnesium and the aluminium powder heaps, the combustion products of the aluminium-magnesium alloy powder on the sand bed were also analysed using the $\mathrm{X}$-ray diffractometer. The results are shown in Fig. 8. The inferences, based on the X-ray diffractometer results, are given in Table 3. From Fig. 8 and Table 3, following inferences are drawn.

The strong reflections corresponding to lattice spacings, $d(\AA)$ of $3.32,2.68,2.41,1.41$ indi-

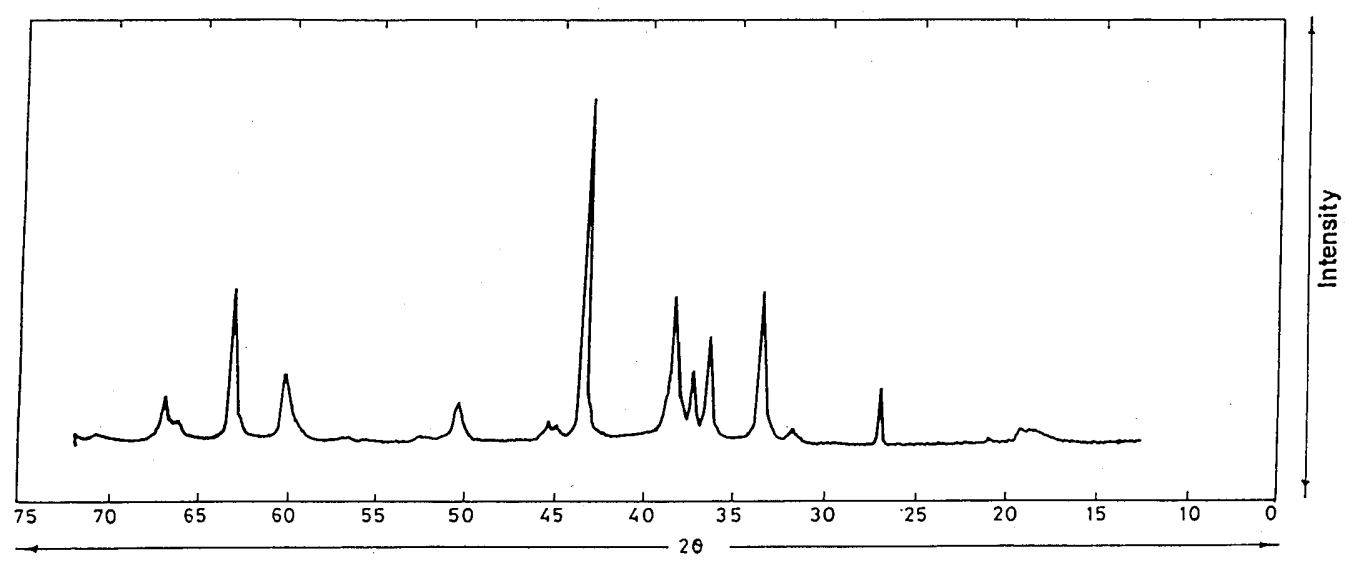

Figure 8. X-ray diffraction pattern of combustion products of the aluminium-magnesium alloy powder heap on the sand bed. 
Table 3 . The X-ray analysis of the combustion products of the aluminium-magnesium alloy powder heap on the sand bed.

\begin{tabular}{|c|c|c|c|c|c|c|c|c|c|c|c|c|c|c|c|}
\hline S.No. & $2 \theta$ & Intensity & $\mathrm{d}(\AA)$ & Spinel & $\begin{array}{c}\text { Magne- } \\
\text { sium Alu- } \\
\text { minate }\end{array}$ & $\begin{array}{c}\text { Magne- } \\
\text { sium Alu- } \\
\text { minium } \\
\text { Oxide }\end{array}$ & $\begin{array}{l}\text { Alumin- } \\
\text { ium Oxide } \\
\text { Alumina }\end{array}$ & Humite & $\begin{array}{l}\text { Alumin- } \\
\text { ium } \\
\text { Oxide }\end{array}$ & $\begin{array}{l}\text { Alumin- } \\
\text { ium } \\
\text { Titanium } \\
\text { Oxide }\end{array}$ & $\begin{array}{c}\text { Magne- } \\
\text { sium } \\
\text { Nitride }\end{array}$ & $\begin{array}{l}\text { Alumin- } \\
\text { ium Mag- } \\
\text { nesium } \\
\text { Oxide }\end{array}$ & $\begin{array}{l}\text { Alumin- } \\
\text { ium }\end{array}$ & $\begin{array}{l}\text { Alumin- } \\
\text { ium } \\
\text { Nitride } \\
\text { (AIN) }\end{array}$ & $\begin{array}{l}\text { Silicon } \\
\text { Dioxide }\end{array}$ \\
\hline 1. & $\begin{array}{l}18.4 \\
18.6\end{array}$ & VVW & 4.7918 & & & $4.614 / 80$ & & & & & & & & & \\
\hline 2. & 19.2 & W & 4.6187 & & & $4.081 / 20$ & $4.6 / 40$ & & & & & & & & \\
\hline 3. & 20.8 & VVW & 4.2669 & & & $3.262 / 40$ & & & & & & & & & $4.04 / 100$ \\
\hline 4. & 26.8 & $\mathrm{~S}$ & 3.3237 & & & $2.817 / 80$ & & & & $3.36 / 100$ & & & & & \\
\hline 5. & 31.5 & W & 2.8376 & $2.87 / 100$ & & $2.74 / 30$ & $2.8 / 20$ & & $2.82 / 80$ & & $2.87 / 20$ & $2.72 / 80$ & & & $2.84 / 14$ \\
\hline 6. & 33.4 & VS & 2.6804 & & & & & & $2.69 / 100$ & $2.66 / 70$ & $2.66 / 27$ & & & $2.70 / 100$ & \\
\hline 7. & 36.2 & $\mathrm{~S}$ & 2.4793 & $2.44 / 100$ & & & & $2.45 / 90$ & & & $2.49 / 20$ & & & $2.49 / 60$ & $2.489 / 18$ \\
\hline 8. & 37.2 & $S$ & 2.4149 & $2.43 / 10$ & $2.44 / 100$ & & $2.40 / 60$ & & & & & & & & \\
\hline 9. & 38.2 & VS & 2.3539 & & & & & & & & & & $2.338 / 100$ & $2.372 / 70$ & $2.342 / 21$ \\
\hline 10. & 43.0 & VVS & 2.1016 & & & & & & & & $2.12 / 42$ & & & & \\
\hline 11. & 44.5 & $W$ & 2.0342 & $2.03 / 80$ & & & & & & & & & $2.024 / 47$ & & \\
\hline 12. & 45.0 & W & 2.0128 & $2.01 / 60$ & $2.02 / 58$ & & $1.99 / 100$ & & & & & & & & \\
\hline 13. & 49.9 & $\mathrm{~S}$ & 1.8260 & & & & & & & & & $1.83 / 48$ & & & \\
\hline 14. & $\begin{array}{l}51.6 \\
52.1\end{array}$ & VWD & 1.7634 & & & & & $1.74 / 100$ & & & $1.76 / 100$ & & & & \\
\hline 15. & 59.5 & $\mathrm{~S}$ & 1.5522 & $1.56 / 80$ & & & & & & & $1.53-1.47$ & & & $1.557 / 30$ & \\
\hline 16. & 62.5 & VS & 1.4847 & & & & & & & & & & & & \\
\hline 17. & 66.2 & $\mathrm{~S}$ & 1.4104 & $1.43 / 100$ & $1.43 / 58$ & & $1.410 / 100$ & & $1.39 / 100$ & & & & $1.431 / 22$ & $1.1414 / 20$ & \\
\hline 18. & $\begin{array}{l}69.5 \\
70.0\end{array}$ & VWD & 1.3479 & $1.37 / 200$ & & & & & & & & & & $1.32 / 18$ & \\
\hline
\end{tabular}

cate the presence of the aluminium oxide.

The strong reflections corresponding to $\mathrm{d}(\AA)$ values of $2.48,2.35,1.55,1.41$ indicate the presence of the aluminium and the magnesium nitride and their oxides as predominant components. It also confirms the reactions of individual active species of the aluminium and the magnesium with atmospheric air at elevated temperatures.

The presence of free aluminium, associated with some spinel $\left(\mathrm{MgO} \mathrm{Al}_{2} \mathrm{O}_{3}\right)$, corresponding to $\mathrm{d}(\AA)$ values of $2.35,1.41$ with 2.41 and 1.55 has also been observed. This is similar to the results obtained for the combustion products of aluminium powder in which case also, unburnt free aluminium was found.

Since titanium is often present in traces as impurity in the aluminium powder heap, the formation of Al-Mg- $\mathrm{T}_{i}$ oxide or Al- $\mathrm{T}_{\mathrm{i}}$ can not be ruled out at incineration temperature of the aluminium metal as minor component in the combustion products.

\section{CONCLUSIONS}

All the individual powders of magnesium, aluminium and aluminium-magnesium alloy (100 g) were placed on sand bed and the burnt product was analysed.

$\mathrm{X}$-ray analysis of the combustion products of the magnesium powder heap on the sand bed reveal that the magnesium oxide is the predominant product followed by its nitride, and hydroxide. Further, absence of free magnesium in combustion products confirm that the magnesium powder has been burnt completely.

As regards the aluminium powder heap, predominant products of combustion are its oxides and nitrides. The presence of aluminium hydroxide has been detected along with free aluminium. 
In the case of aluminium-magnesium alloy powder heap, it is noted that the combustion products include the oxides, nitrides, hydroxides of both the aluminium and the magnesium along with free aluminium.

\section{ACKNOWLEDGEMENTS}

The authors are grateful to Dr.S.K. Misra, Acting Director, CBRI, Roorkee for according permission for publication of the paper in the Fire Science and Technology. They are thankful to Dr.J.M. Bhatnagar and Mr.Jagbir Singh for their help. They also acknowledge the efforts of Mr. Pravez Alam and Miss Deepti Gupta in typing the manuscript.

\section{REFERENCES}

1. Hartman, I, Nagy, J. and Brown, H.R., 'Inflammability and Explosibility of Metal Powders', U.S. Bureau of Mines Report, R.I. No.3722, 1943.

2. Gregg, S.J. and Jepson, W.B., Journal of the Institute of Metals, 87, (1958-59), p.187.

3 . Brown, C.R., Handbook of Fire Prevention, National Fire Protection Association 9th Edition (1941), p.1208.

4. Sharma, T.P., Studies on the Burning Behaviour of Metal Powder Fires and their Extinguishment, $\mathrm{Ph}$. D. Thesis, University of Roorkee (India), 1989.

5. Markstein, G.H., Eleventh Symposium International) on Combustion, The Combustion Institute, Pittsburggh 1967, p.219.

6. Yuasa, S. and Takeno, T., Memoirs of Metropolitan College of Technology, Tokyo No.11 (1983), p.169.

7. Markstein, G.H., 12th Symposium (International) on Combustion, The Combustion Institute, Pittsburgh 1969, p.733.

8. Yuasa, S. and Isoda, H., Twenty second Symposium (International) on Combustion, The Combustion Institute, Pittsburgh, PA, 1988.

9. Yuasa, S., Ph.D. Thesis, University of Tokyo, 1978.
10. Brzustowski, T.A. and Glassman, I., in AIAA Progress in Aeronautics and Astronautics, Eds. H.G. Wolfhard et al, Academic Press, New York, 15, 1966, p.166.

11. Sullivan, H.F. and Glassman, I., Combustion Science and Technology, 4, 1972, p.241.

12. Takeno, T. and Yuasa, S., Combustion Science and Technology, 21, 1980, p.109.

13. Varshney, B.S., Kumar, S. and Sharma, T.P., Fire Safety Journal, Vol. 16, No.1, 1990, pp. 93-116(accepted).

14. Index to X-ray Powder Data File, American Society for Testing and Materials, Philadelphia, 3, 1958. 